\title{
Effect of Oil Spillage on Groundwater Quality
}

Keywords: Spillage; Pollution; Groundwater; Investigation; Gokhana Abstract

Investigation of the effect of oil spillage on groundwater quality was conducted using the spill-affected areas of Gokhana Local Government as the study area and the unaffected areas of Khana Local Government as the control. Groundwater samples were obtained from hand dug wells in the study and control areas and analysed. Water parameters such as temperature, $\mathrm{pH}$, dissolved oxygen (DO) biochemical oxygen demand (BOD) and total hydrocarbon conten (THC) were determined and compared for the two areas on the one hand and with available standards on the other hand. The results obtained revealed a significant increase in temperature with a mean of $28.13 \pm 0.35^{\circ} \mathrm{C}$, decrease in $\mathrm{pH}$ with a mean of $4 \pm 0.22$, decrease in DO with a mean of $2.2 \pm 0.36 \mathrm{mg} / \mathrm{l}$, increase in BOD with a mean of $12.5 \pm 2.27 \mathrm{mg} / \mathrm{l}$ and increase in THC with a mean of $1.4 \pm 0.34 \mathrm{mg} / \mathrm{l}$ in the study area compared with the control area and the standards. It was concluded that the groundwater in the study area is polluted and should be treated before use.

\section{Introduction}

Groundwater is one of the most valuable natural resources which support human health, social and economic development and ecological diversity. It is a renewable natural resource which is vulnerable to natural and human impacts. Little attention was paid to the protection of groundwater quality for a long time as people were unaware of the dangers imposed on this essential resource and thus the idea that the geological environment protects the groundwater quality prevailed for some times. Although the physical environment provides some level of protection for groundwater system, contaminants still find their way into drinking water aquifers by infiltrating through the soil profile, and in most cases transporting the contaminants to other aquifers in the direction of groundwater flow [1-3]

Groundwater pollution is a process whereby water gradually or suddenly changes its physical, chemical or biological composition and ceases to meet the standards set for drinking water, irrigation and other purposes. Groundwater pollution by crude oil is a serious social, economic and environmental problem worldwide [2,4]. Groundwater constitutes an important source of water for domestic supply and agricultural use and if it contains toxic compounds, it becomes dangerous for people and terrestrial ecosystems [5].

Since the first shipment of crude oil in 1958, there has been an upsurge in oil exploration activities in Nigeria which has led to the discovery of numerous oil fields and subsequently to the development of various oil terminals $[2,6]$. Oil extraction is a complicated process that has the potential for unfortunate consequences such as oil spills [2]. Oil spillage has been a major occurrence in oil producing communities of Nigeria, thereby causing a major threat to surface and groundwater resources of the affected areas. Oil spills on land are more readily containable but also deadly due to infiltration which could percolate to the underlying soil layers and thereby contaminate the groundwater [3]. Oil spillage occurs due to several causes, including
Journal of

Environmental Studies

\author{
Ejikeme Ugwoha* and Benedict Emeka Omenogor \\ Department of Environmental Engineering, University of Port \\ Harcourt, P.M.B. 5323, Nigeria \\ *Address for Correspondence \\ Ejikeme Ugwoha, Department of Environmental Engineering, University \\ of Port Harcourt, PMB 5323, Nigeria, Tel: 080 31181050; E-mail: \\ ugwohaej@yahoo.com \\ Submission: 10 March, 2017 \\ Accepted: 04 April, 2017 \\ Published: 11 April, 2017 \\ Copyright: ๑ 2017 Ejikeme U. This is an open access article distributed \\ under the Creative Commons Attribution License, which permits \\ unrestricted use, distribution, and reproduction in any medium, provided \\ the original work is properly cited.
}

leaks from old corroded and poorly maintained pipelines and tankers (accounting for $50 \%$ of all oil spills), exploration and production operation (22\%) and sabotage (28\%) [7]. The dire consequences of these oil spills are majorly borne by the host communities where exploration takes place. Also, the pipe networks for transporting oil to different terminals have further drawn the danger closer to several neighbouring communities [1].

Oil spillage is a serious problem in Ogoni, particularly in Gokhana Local Government Area. This is because the aquifers upon which the inhabitants depend for drinking water are shallow, and can be polluted by infiltration of spilled oil within a short pace of time. Groundwater pollution from oil spill is not always amenable to total clean up [8]. Prolonged consumption of oil polluted water has adverse effect on the health of the consumers. Water with high level of hydrocarbon content may have negative effect on the kidney and liver of the consumers. Also, poor reproductive system, leukemia, increased blood pressure and reduced blood clotting are associated with the consumption of oil polluted water [2]. Therefore, it is important to ascertain if the groundwater in Gokhana is polluted with oil or not.

\section{Materials and Methods}

\section{Study area}

This study was conducted in Gokhana Local Government Area, Rivers State, Nigeria. Gokhana is located within the South East Senatorial Zone of Rivers State and has both riverine and upland communities. It is also one of the major oil-producing areas in Rivers State and shares boundaries with Tai in the North, Khana in the East, $\mathrm{Ogu} /$ Bolo in the west and Bonny in the south. It is situated at $50 \mathrm{~km}$ south of Port Harcourt and $30 \mathrm{~km}$ from Onne industrial area [9].

Gokhana is located in the Niger Delta Basin between latitude $4^{\circ} 36^{\prime} \mathrm{N}$ and longitude $7^{\circ} 21^{\prime} \mathrm{E}$. It has an area of $126 \mathrm{~km}^{2}$ and a population of 301,828 according to 2006 census. The area is characterized by alternate wet and dry seasons, the rainy season starts in late April to October with the peak in July to September. It experiences an average annual rainfall of about $250 \mathrm{~cm}$ which diminishes in October. The 
Table 1: Locations and identification codes of the water samples used.

\begin{tabular}{|c|c|c|c|}
\hline \multicolumn{2}{|l|}{ Sample location } & \multirow{2}{*}{$\begin{array}{l}\text { Source } \\
\text { Hand-dug well }\end{array}$} & \multirow{2}{*}{$\begin{array}{l}\text { Identification code } \\
\text { GW I }\end{array}$} \\
\hline \multirow{4}{*}{$\begin{array}{l}\mathrm{G} \circ \mathrm{k} \mathrm{h} \text { a } \mathrm{n} \text { a } \\
\text { (Study area) }\end{array}$} & Bodo & & \\
\hline & K-dere & Hand-dug well & GW 2 \\
\hline & Mogho & Hand-dug well & GW 3 \\
\hline & B-dere & Hand-dug well & GW 4 \\
\hline \multirow{4}{*}{$\begin{array}{l}\text { Khana } \\
\text { area) }\end{array}$} & Bunu-bagha & Hand-dug well & GW 5 \\
\hline & Bori & Hand-dug well & GW 6 \\
\hline & Lude-Luoeku & Hand-dug well & GW 7 \\
\hline & Taabaa & Hand-dug well & GW 8 \\
\hline
\end{tabular}

Table 2: Characteristics of groundwater samples from Gokhana.

\begin{tabular}{|l|l|l|l|l|l|l|l|}
\hline Parameter & GW1 & GW2 & GW3 & GW4 & MEAN & WHO & $\begin{array}{l}\text { N S D W Q I } \\
\text { DPR }\end{array}$ \\
\hline Temp. $\left({ }^{\circ} \mathrm{C}\right)$ & 27.7 & 28 & 28.5 & 28.3 & 28.13 & 25 & 25 \\
\hline pH & 3.7 & 4.0 & 4.2 & 4.1 & 4.0 & $6.5-8.5$ & $6.2-9.2$ \\
\hline DO $(\mathrm{mg} / \mathrm{L})$ & 2.4 & 1.82 & 1.98 & 2.6 & 2.2 & $>3$ & NA \\
\hline BOD $(\mathrm{mg} / \mathrm{L})$ & 15.7 & 12.4 & 10.5 & 11.4 & 12.5 & 10 & NA \\
\hline THC $(\mathrm{mg} / \mathrm{L})$ & 1.8 & 1.5 & 0.98 & 1.32 & 1.4 & 0.05 & 0.3 \\
\hline
\end{tabular}

NA: Not Available

dry season lasts from November to March with the periodic dust laden harmattan winds between December and February. The area experiences a relative humidity of over $90 \%$ and mean temperature of $27^{\circ} \mathrm{C}[10]$.

The Presence of flow stations including numerous pipelines that crisscross Gokhana land and seascape render the area highly vulnerable to oil spills. More so, oil spillages from these pipelines do occur resulting in environmental degradation. The pipeline that cuts across the study area is a Trans-Niger trunk line that transports 120,000 to 150,000 barrels of crude oil per day, running from the hinterlands through Gokhana and link to the Bonny terminal where the NNPC Bonny to Port Harcourt Refinery trunkline transports crude oil from the Bonny terminal to the Port Harcourt Refinery [11].

Water samples were collected from four selected wells within the study area (Gokhana) and four other wells in the control area (Khana). The locations of these water samples are described in Table 1.

\section{Groundwater sampling}

Representative samples of groundwater were collected from four hand-dug wells in four different locations in both the study and control areas. The groundwater samples were transferred into sample bottles and carefully labelled with the appropriate identification codes. Prior to collection, and as part of quality control measures, all bottles were washed with non-ionic detergent and rinsed with deionized water before usage. Also, the sample bottles were rinsed three times with the groundwater samples. Samples for total hydrocarbon content were acidified with $2 \mathrm{ml}$ concentrated sulphuric acid using 1-liter bottles. The labeled groundwater samples were taken to the laboratory in coolers of ice for analysis within 24 hours.

\section{Groundwater sample analysis}

The groundwater samples from the study area and the control area were subjected to laboratory analysis to determine their properties. These water parameters include temperature, $\mathrm{pH}$, dissolved oxygen
(DO), biochemical oxygen demand (BOD) and total hydrocarbon content (THC).

The temperature of the groundwater sample was obtained simultaneously with $\mathrm{pH}$ using the Winlab $\mathrm{pH}$ and temperature meter. To determine DO, the groundwater samples were fixed with Winkler solution I (manganese sulphate) and Winkler solution II (potassium iodide and sodium azide). Exactly 50\% sulphuric acid (4 ml) was added to the precipitate formed on fixing with Winkler solution I and II. The solution was then titrated with standard $0.0125 \mathrm{M}$ thiosulphate $\left(\mathrm{Na}_{2} \mathrm{~S}_{2} \mathrm{O}_{3} \cdot 5 \mathrm{H}_{2} \mathrm{O}\right)$ to a light yellow coloured solution. Exactly two drops of starch indicator were added to the light yellow coloured solution and it became blue and titration was continued until the blue colour became colourless. Then DO was calculated using Equation (1) [12]:

$$
\text { DO }(\mathrm{mg} / \mathrm{l})=\text { Volume of } 0.0125 \mathrm{M} \mathrm{Na}_{2} \mathrm{~S}_{2} \mathrm{O}_{3} \cdot 5 \mathrm{H}_{2} \mathrm{O} \text { used }
$$

To determine the BOD of the groundwater sample, the DO of the groundwater sample was first determined. Thereafter, the groundwater sample was incubated in the dark at $20^{\circ} \mathrm{C}$ for five days, and the $\mathrm{DO}$ was then determined. The $\mathrm{BOD}_{5}$ was then calculated using Equation (2) [12]:

$$
\mathrm{BOD}_{5}=\mathrm{DO}_{1}-\mathrm{DO}_{5}
$$

where $\mathrm{DO}_{1}=\mathrm{DO}$ at day one (before incubation) and $\mathrm{DO}_{5}=\mathrm{DO}$ at the fifth day of incubation.

THC of the groundwater sample was determined using the liquid-liquid, partition-gravimetric extraction procedure as outlined in APHA 5520 B [12]. Toluene was used as the extracting solvent. Exactly $100 \mathrm{ml}$ of the groundwater sample was transferred into a separating funnel and $10 \mathrm{ml}$ of toluene was added. The absorbance of the toluene extract was then measured with the aid of a spectrophotometer at $420 \mathrm{~nm}$ wavelength. The spectrophotometer reading was then converted to parts per million by reference to a standard curve which was prepared using known concentrations of hydrocarbons in the extractant.

\section{Results and Discussion}

\section{Characteristics of groundwater samples}

The characteristics of groundwater samples from Gokhana LGA (study area) and Khana LGA (control) are presented in Tables 2 and 3, respectively. The temperature readings of the groundwater samples in the study area varied between $27.7^{\circ} \mathrm{C}$ and $28.5^{\circ} \mathrm{C}$ with a mean value of $28.13 \pm 0.35$ while that of the control area varied between $26.2^{\circ} \mathrm{C}$ and $27.5^{\circ} \mathrm{C}$ with a mean value of $26.88 \pm 0.54$ which is slightly higher than the World Health Organization (WHO) and the Nigerian Standard for Drinking Water Quality/Department of Petroleum Resources (NSDWQ/DPR) standards of $25{ }^{\circ} \mathrm{C}$. The increase in temperature in the study area could be due to increased rate of chemical reaction resulting from the presence oil in the groundwater.

The $\mathrm{pH}$ values in the study area ranged from 3.7 to 4.2 which is acidic, while the $\mathrm{pH}$ value in the control area ranged from 6.2 to 7.5 which is within the NSDWQ/DPR recommended range of 6.2 to 9.2. The low $\mathrm{pH}$ values observed in the study area indicates contamination of the groundwater due to oil spillage.

Dissolved oxygen (DO) in the study area ranged from $1.82 \mathrm{mg} / \mathrm{l}$ 
ISSN: $2471-4879$

Table 3: Characteristics of groundwater samples from Khana.

\begin{tabular}{|l|l|l|l|l|l|l|l|l|l|l|}
\hline Parameter & GW5 & GW6 & GW7 & GW8 & MEAN & WHO \\
\hline Temp. $\left({ }^{\circ} \mathrm{C}\right)$ & 26.8 & 27.5 & 27 & 26.2 & 26.88 & 25 \\
\hline $\mathrm{pH}$ & 6.4 & 7.5 & 6.9 & 6.2 & 6.75 & $6.5-8.5$ \\
\hline $\mathrm{DO}(\mathrm{mg} / \mathrm{L})$ & 6.3 & 5.8 & 5.97 & 6.61 & 6.17 & $>3$ \\
\hline BOD $(\mathrm{mg} / \mathrm{L})$ & 4.5 & 3.7 & 3.8 & 4.8 & 4.2 & 10 & NA \\
\hline THC $(\mathrm{mg} / \mathrm{L})$ & ND & ND & ND & ND & ND & 0.05 \\
\hline
\end{tabular}

ND: Not Detected; NA: Not Available

to $2.6 \mathrm{mg} / \mathrm{l}$ with a mean value of $2.2 \pm 0.36 \mathrm{mg} / \mathrm{l}$ which is less than WHO standard of $>3.0 \mathrm{mg} / \mathrm{l}$, while that of the control area ranged from $5.8 \mathrm{mg} / \mathrm{l}$ to $6.61 \mathrm{mg} / \mathrm{l}$ with a mean value of $6.17 \pm 0.36 \mathrm{mg} / \mathrm{l}$ which is greater than the recommended WHO standard. The low levels of DO in the study area imply that the groundwater is polluted with organic materials whose breakdown is gradually depleting the available oxygen.

The biochemical oxygen demand (BOD) in the study area ranged from $10.5 \mathrm{mg} / \mathrm{l}$ to $15.7 \mathrm{mg} / \mathrm{l}$ with a mean value of $12.5 \pm 2.27 \mathrm{mg} / \mathrm{l}$ which is greater than the recommended WHO standard of $10 \mathrm{mg} / \mathrm{l}$, while that of the control area ranged from $3.7 \mathrm{mg} / \mathrm{l}$ to $4.8 \mathrm{mg} / \mathrm{l}$ with a mean value of $4.2 \pm 0.54 \mathrm{mg} / \mathrm{l}$ which is less than the recommended WHO standard. Thus, it can be said that the groundwater in the study area is contaminated with organic pollutants.

The total hydrocarbon content (THC) in the study area ranged from $0.98 \mathrm{mg} / \mathrm{l}$ to $1.80 \mathrm{mg} / \mathrm{l}$ with a mean value of $1.4 \pm 0.34 \mathrm{mg} / \mathrm{l}$ which is greater than the WHO and NSDWQ/DPR standards of $0.05 \mathrm{mg} / \mathrm{l}$ and $0.3 \mathrm{mg} / \mathrm{l}$, respectively. Contrarily, THC was beyond detection level in the control area. This result is a clear indication of hydrocarbon pollution of groundwater in the study area and accounts for the high BOD recorded in the study area.

Oil spillage is associated with low DO concentration, increased $\mathrm{BOD}$, increased water temperature, presence of organic impurities and acidity of groundwater $[8,13]$. This is evident in the study area when compared with the control area.

\section{Conclusion}

The impact of oil spillage on groundwater quality in Gokhana Local Government Area was investigated via the analysis of collected groundwater samples and comparing same with that of a control area (Khana Local Government Area) and available standards. The results obtained indicate the presence of total hydrocarbons in the study area, with a mean value of $1.4 \pm 0.34 \mathrm{mg} / \mathrm{l}$, but absent in the control area, signifying the contamination of the groundwater in the study area. Other indications of contamination of the groundwater in the study area are low $\mathrm{pH}$ with a mean value of $4 \pm 0.22$, low dissolved oxygen (DO) with a mean value of $2.2 \pm 0.36 \mathrm{mg} / \mathrm{l}$ and high biochemical oxygen demand (BOD) with a mean value of $12.5 \pm 2.27 \mathrm{mg} / \mathrm{l}$ compared with the World Health Organization (WHO) and the Nigerian Standard for Drinking Water Quality/Department of Petroleum Resources (NSDWQ/DPR) standards. On the contrary, these parameters ( $\mathrm{pH}$, DO and BOD) were within the WHO and available NSDWQ/DPR standards in the control area. Therefore, it is concluded that the oil spill in the study area has polluted the groundwater.

\section{References}

1. Abidoye LK, Wairagu MR (2013) Simulation of oil spill infiltration and redistribution in a shallow aquifer. Afr J Environ Sci Technol 7: 546-554.

2. Gay J, Shepherd O, Thyden M, Whitman M (2010) The health effects of oil contamination: A compilation of research. Worcester Polytechnic Institute, pp. 198.

3. Duffy JJ, Peake E, Mohtadi MF (1980) Oil spills on land as potential sources of groundwater contamination. Environ Int 3: 107-120.

4. Delin GN, Essaid HI, Cozzarelli IM, Lahvis MH, Bekins BA (1998) Ground water contamination by crude oil near Bemidji, Minnesota: Fact Sheet 08498. US Geological Survey (USGS).

5. Vrba J (2002) The impact of aquifer intensive use on groundwater quality. In: Llamas R, Custodio E (Eds). Intensive use oof groundwater: Challenges and opportunities. AA Balkema Publishers, Tokyo, pp. 113-132.

6. Ozobia NV (1998) Engineering challenges in the Nigerian Maritime Industry. Third Engineering lecture. Faculty of Engineering University of Lagos. Proceedings of the 1981 International Seminar.

7. Nwilo SF, Okpala KA, Nwoke HA (2007) Impact of spill on the ecosystem. UNN Publishing, Nsukka.

8. Nwachukwu AN, Osuagwu J (2013) Effects of oil spillage on groundwater quality in Nigeria. Am J Eng Res 3: 271-274.

9. UNEP (2011) Environmental assessment of Ogoni land report. United Nations Environment.

10. Short KC, Stauble AJ (1967) Outline geology of the Niger Delta. AAPG Bull 51: 761-779.

11. Morris BL, Lawrence AR, Chilton PJ, Adams B, Calow RC, et al. (2003) Groundwater and its susceptibility to degradation: A global assessment of the problem and options for management. United Nations Environment Programme, pp. 126.

12. Rice EW, Baird RB, Eaton AD, Clesceri LS (2012) Standard methods for examination of water and wastewater, $\left(22^{\text {nd }} e d n\right)$. American Public Health Association, American Water Works Association, Water Environment Federation, Washington DC.

13. Ojiegbe RU (2006) Assessment of the effects of oil spillage on groundwater in an inland basin of southeastern Nigeria. Int J Nat Appl Sci 2: 19-23.
Acknowledgements

The Authors wish to thank the University of Port Harcourt for providing the opportunity to carry out this research. 